www.jmscr.igmpublication.org

Impact Factor 5.84

Index Copernicus Value: 83.27

ISSN (e)-2347-176x ISSN (p) 2455-0450

crossref DOI: _https://dx.doi.org/10.18535/jmscr/v5i3.127

Journal Of Medical Science And Clinical Research

IGM Publication

An Official Publication of IGM Publication

\title{
Determination of Age from Epiphyseal Union of Bones at Shoulder Joint in Boys in Bikaner Region
}

\author{
Authors \\ Dr Sanjeev Buri ${ }^{1}$, Dr Pramod Kumar Saini ${ }^{2}$, Dr Amit Joshi ${ }^{3}$, Dr Manoj Garg ${ }^{4}$ \\ ${ }^{1}$ Assistant Professor, Dept. of Forensic Medicine \& Toxicology, S.P. Medical College, Bikaner, Rajasthan \\ ${ }^{2}$ Assistant Professor, Dept. of Forensic Medicine \& Toxicology, S.P. Medical College, Bikaner, Rajasthan \\ Email: drpramodkumarsaini@gmail.com, Mobile no.: 9352587597 \\ ${ }^{3}$ Assistant Professor, Dept. of Forensic Medicine \& Toxicology, Govt. Medical College, Kota, rajasthan \\ ${ }^{4}$ Senior Demonstrator, Dept. of Forensic Medicine \& Toxicology, S.P. Medical College \& Associate Group \\ of Hospitals, Bikaner, Rajasthan \\ Email: dr.manojgarg72@gmail.com, Mobile no.: 9414357945 \\ Corresponding Author \\ Dr Sanjeev Buri \\ Email: drsanjeevburi@gmail.com, Mobile no.: 9314092038
}

\begin{abstract}
Background: The study of epiphyseal union of bones is considered a reasonably accurate and accepted method for age determination. There is a variation in the timing of appearance and fusion of the epiphyses of the bones. So, the present work is to investigate the ages of epiphyseal union around shoulder joint radiologically in boys Bikaner region.
\end{abstract}

Material \& Methods: The present study has been conducted on 107 boys falling in the age group of 14-25 years, which are selected randomly from various local educational institutions, neighbourhood of various faculty members and staff as well as cases attending the OPD of the Forensic Medicine Department of PBM Hospital, Bikaner.

Results: In our study shows the complete fusion seen in 16-17 years of age group of the coracoids process, 19 20 years of age group of acromian process and 18-19 years of age group of the head of humerus in boys.

Conclusion: In concluded that determine whether an individual has already reached the criminal responsibility age (18 years) or not; evaluation of epiphysis of shoulder joint closure is important after closure of hand and wrist bone epiphyses just before evaluation of iliac crest and ischial tuberosity fusion.

Keywords: Epiphysis, Coracoids process, acromian process, head of Humerus.

\section{Introduction}

Determination of age of an individual whether living, dead or from human remains is a vexing problem for medical jurist in both civil and criminal matters. Age estimation cases are often referred to forensic experts as it is a very important issue to the court of law and to common $\operatorname{man}^{1}$.
In law the crime and punishment is entirely based on criminal responsibility and this in turn depend on the age of a person. Age is helpful in identification of an individual which in turn is helpful in both civil and criminal cases. The study of epiphyseal union of bones is considered a reasonably accurate and accepted method for age determination. Despite the fact that there are a 
number of laws requiring registration of births (e.g. Registration of births and deaths Act 1969) most births are not properly recorded. There is a variation in the timing of appearance and fusion of the epiphyses of the bones ${ }^{1}$.

Reddy KSN (2009) stated that the bones of human skeleton develop from a number of ossification centers. $^{2}$

The complexity of overall ossification problem may be gleaned by the estimation that at the $11^{\text {th }}$ prenatal week in humans there are some 806 centers of bone growth, at birth about 450 , while the adult skeleton has only 206 bones $^{3}$.

It is an established fact that the sequence and ultimate ossification of epiphysis varies in both sexes in different part of the world to the extent that there are wide variation even in the population of the different states of a country ${ }^{4}$. Jit and Kulkarni revealed that Precocity of epiphyseal union has been attributed to racial and climatic factors. ${ }^{5}$ So, the present work is to investigate the ages of epiphyseal union around shoulder joint radiologically in boys Bikaner region.

\section{Material \& Methods}

The present study has been conducted on 107 boys, which are selected randomly from various local educational institutions, neighbourhood of various faculty members and staff as well as cases attending the OPD of the Forensic Medicine Department of PBM Hospital, Bikaner, falling in the age group of 14-25 years, in order to understand the pattern of appearance of ossification centre and fusion of diaphysio epiphyseal union in coracoids, acromian process, head of humerus in shoulder joint by radiological examination.

In school going subjects, date of birth was confirmed from the verbal statement, record of school, secondary school certificate etc. All the subjects were bona fide resident of Rajasthan and are residing in Bikaner region for more than 5 years and were free from physical and mental illness, disability, and long lasting disease. Informed expressed verbal consent of each subject was taken before his/her physical and radiological examination. Exclusion criteria: 1. The subjects should not have any nutritional deficiency, endocrinal disorders, history of chronic drug intake (e.g.) anti-epileptic drugs, steroids, bony deformity or pathology, congenital malformation, and chronic illness thus affecting the skeletal growth and development of the individual. 2 . Those who have no valid Date of Birth certificates.

For analysis of observation and discussion the whole process of epiphyseal union divided into three stages:

1. Centre of Ossification not appeared.

2. Centre of Ossification appeared but union is not.

3. Complete union with or without scar line.

\section{Results}

The observation shows the partial fusion seen in $30.00 \%$ cases in $14-15$ years of age group \& $85.71 \%$ cases in $15-16$ years of age group. Complete fusion seen in $100 \%$ cases from 16-17 years to 24-25 years of age group of the coracoids process in boys (table 1).

The observation shows the appearance in $100 \%$ case from 15-16 years to 24-25 years of age group. Partial fusion seen in $85.14 \%$ cases in 1617 years of age group, $80.00 \%$ cases in $17-18$ years of age group \& $75.00 \%$ cases in $18-19$ years of age group. complete fusion seen in $100 \%$ cases from 19-20 years to 24-25 years of age group. No fusion seen in 14-15 years \& 15-16 years of age group of acromian process in boys (table 2 ).

The observation shows the partial fusion seen in $40.00 \%$ cases in $14-15$ years of age group, $14.28 \%$ cases in 15-16 years, $100 \%$ cases in $16-17$ years of age group \& $70.00 \%$ cases in $17-18$ years of age group. Complete fusion seen in $30.00 \%$ cases in $17-18$ years \& $100 \%$ cases from $18-19$ years to 24-25 years of age group of the head of humerus in boys. 
Table no. 1: Appearance and Fusion Coracoid Process in Males

\begin{tabular}{|c|c|c|c|c|c|c|c|c|}
\hline \multirow{2}{*}{ S. No. } & \multirow{2}{*}{$\begin{array}{c}\text { Age } \\
(\mathrm{yrs})\end{array}$} & \multirow{2}{*}{$\begin{array}{l}\text { No. of } \\
\text { Cases }\end{array}$} & \multicolumn{2}{|c|}{ Appearance } & \multicolumn{2}{|c|}{ Partial Fusion } & \multicolumn{2}{|c|}{ Fusion } \\
\hline & & & No. & $\%$ & No. & $\%$ & No. & $\%$ \\
\hline 1 & $14-15$ & 10 & 10 & $100 \%$ & 3 & $30 \%$ & - & - \\
\hline 2 & $15-16$ & 7 & 7 & $100 \%$ & 6 & $85.71 \%$ & - & - \\
\hline 3 & $16-17$ & 7 & 7 & $100 \%$ & - & - & 7 & $100 \%$ \\
\hline 4 & $17-18$ & 10 & 10 & $100 \%$ & - & - & 10 & $100 \%$ \\
\hline 5 & $18-19$ & 16 & 16 & $100 \%$ & - & - & 16 & $100 \%$ \\
\hline 6 & $19-20$ & 8 & 8 & $100 \%$ & - & - & 8 & $100 \%$ \\
\hline 7 & $20-21$ & 15 & 15 & $100 \%$ & - & - & 15 & $100 \%$ \\
\hline 8 & $21-22$ & 14 & 14 & $100 \%$ & - & - & 14 & $100 \%$ \\
\hline 9 & $22-23$ & 8 & 8 & $100 \%$ & - & - & 8 & $100 \%$ \\
\hline 10 & $23-24$ & 7 & 7 & $100 \%$ & - & - & 7 & $100 \%$ \\
\hline 11 & $24-25$ & 5 & 5 & $100 \%$ & - & - & 5 & $100 \%$ \\
\hline
\end{tabular}

Table no. 2: Appearance and Fusion of Acromian Process in boys

\begin{tabular}{|l|c|c|c|c|c|c|c|c|}
\hline \multirow{2}{*}{ S. No. } & \multirow{2}{*}{$\begin{array}{c}\text { Age } \\
(\mathbf{y r s})\end{array}$} & \multirow{2}{*}{$\begin{array}{c}\text { No. of } \\
\text { Cases }\end{array}$} & \multicolumn{2}{|c|}{ Appearance } & \multicolumn{2}{c|}{ Partial Fusion } & \multicolumn{2}{|c|}{ Fusion } \\
\cline { 5 - 9 } & & & No. & $\%$ & No. & \% & No. & $\%$ \\
\hline 1 & $14-15$ & 10 & 6 & $60 \%$ & - & - & - & - \\
\hline 2 & $15-16$ & 7 & 7 & $100 \%$ & - & - & - & - \\
\hline 3 & $16-17$ & 7 & 7 & $100 \%$ & 6 & $85.14 \%$ & - & - \\
\hline 4 & $17-18$ & 10 & 10 & $100 \%$ & 8 & $80 \%$ & 2 & $20 \%$ \\
\hline 5 & $18-19$ & 16 & 16 & $100 \%$ & 12 & $75 \%$ & 4 & $25 \%$ \\
\hline 6 & $19-20$ & 8 & 8 & $100 \%$ & - & - & 8 & $100 \%$ \\
\hline 7 & $20-21$ & 15 & 15 & $100 \%$ & - & - & 15 & $100 \%$ \\
\hline 8 & $21-22$ & 14 & 14 & $100 \%$ & - & - & 14 & $100 \%$ \\
\hline 9 & $22-23$ & 8 & 8 & $100 \%$ & - & - & 8 & $100 \%$ \\
\hline 10 & $23-24$ & 7 & 7 & $100 \%$ & - & - & 7 & $100 \%$ \\
\hline 11 & $24-25$ & 5 & 5 & $100 \%$ & - & - & 5 & $100 \%$ \\
\hline
\end{tabular}

Table no. 3: Appearance and Fusion of the centre of Head of Humerus in boys

\begin{tabular}{|c|c|c|c|c|c|c|c|c|}
\hline \multirow{2}{*}{ S. No. } & \multirow{2}{*}{$\begin{array}{l}\text { Age } \\
\text { (yrs) }\end{array}$} & \multirow{2}{*}{$\begin{array}{l}\text { No. of } \\
\text { Cases }\end{array}$} & \multicolumn{2}{|c|}{ Appearance } & \multicolumn{2}{|c|}{ Partial Fusion } & \multicolumn{2}{|c|}{ Fusion } \\
\hline & & & No. & $\%$ & No. & $\%$ & No. & $\%$ \\
\hline 1 & $14-15$ & 10 & 10 & $100 \%$ & 4 & $40 \%$ & - & - \\
\hline 2 & $15-16$ & 7 & 7 & $100 \%$ & 1 & $14.28 \%$ & - & - \\
\hline 3 & $16-17$ & 7 & 7 & $100 \%$ & 7 & $100 \%$ & - & - \\
\hline 4 & $17-18$ & 10 & 10 & $100 \%$ & 7 & $70 \%$ & 3 & $30 \%$ \\
\hline 5 & $18-19$ & 16 & 16 & $100 \%$ & - & - & 16 & $100 \%$ \\
\hline 6 & $19-20$ & 8 & 8 & $100 \%$ & - & - & 8 & $100 \%$ \\
\hline 7 & $20-21$ & 15 & 15 & $100 \%$ & - & - & 15 & $100 \%$ \\
\hline 8 & $21-22$ & 14 & 14 & $100 \%$ & - & - & 14 & $100 \%$ \\
\hline 9 & $22-23$ & 8 & 8 & $100 \%$ & - & - & 8 & $100 \%$ \\
\hline 10 & $23-24$ & 7 & 7 & $100 \%$ & - & - & 7 & $100 \%$ \\
\hline 11 & $24-25$ & 5 & 5 & $100 \%$ & - & - & 5 & $100 \%$ \\
\hline
\end{tabular}

\section{Discussion}

The present study has been conducted on 107 boys, which are selected randomly in school going subjects, date of birth was confirmed from the verbal statement, record of school, secondary school certificate etc.
In this study shows the partial fusion seen in $30.00 \%$ cases in $14-15$ years of age group \& $85.71 \%$ cases in $15-16$ years of age group. Complete fusion seen in $100 \%$ cases from 16-17 years to 24-25 years of age group of the coracoids process in boys. This study consistent with 
Galastaun $^{6}$, Chaurassia B.D. ${ }^{7}$ T.A. Gonzales ${ }^{8}$, Peter L. Williams ${ }^{9}$ and SC Shanks ${ }^{10}$ and in consistent with L.A. Waddae ${ }^{11}$, C.K. Parikh, K.S ${ }^{12}$. Narayan Reddy ${ }^{2}$, F.E. Camps ${ }^{13}$, J.V. Basmajian ${ }^{14}$ and Krogman ${ }^{15}$.

The present study shows the appearance in $100 \%$ case from 15-16 years to 24-25 years of age group. Partial fusion seen in $85.14 \%$ cases in 16 17 years of age group, $80.00 \%$ cases in $17-18$ years of age group \& $75.00 \%$ cases in $18-19$ years of age group. complete fusion seen in $100 \%$ cases from 19-20 years to 24-25 years of age group. No fusion seen in 14-15 years \& 15-16 years of age group of acromian process in boys. In case of boys findings of present study for Acromian Process corresponds with Pillai ${ }^{16}$, Galastaun ${ }^{6}$, KS Narayan Reddy $^{2}$, JV. Basmajian ${ }^{14}$, Flecker ${ }^{17}$, Bernard Knight $^{18}$ and Krogman ${ }^{15}$ and not in accordance with C.K. parikh ${ }^{12}$, Chaurassia B.D. ${ }^{7}$, T.A. Gonzales ${ }^{8}$, F.E. Camps ${ }^{13}$, Peter L. Williams ${ }^{9}$, S.C. Shanks ${ }^{10}$.

The present study observed that the partial fusion seen in $40.00 \%$ cases in 14-15 years of age group, $14.28 \%$ cases in $15-16$ years, $100 \%$ cases in $16-17$ years of age group \& $70.00 \%$ cases in $17-18$ years of age group. Complete fusion seen in $30.00 \%$ cases in 17-18 years \& $100 \%$ cases from $18-19$ years to 24-25 years of age group of the head of humerus in boys. In Case of boys findings of Head of humerus in present study are in accordance with the L.A. Waddel ${ }^{11}$, Galastaun ${ }^{6}$, T.A. Gonzales ${ }^{8}$, J.V. Basmajian ${ }^{14}$ and not in accordance with Lall and $\mathrm{Nat}^{19}$, Pillai ${ }^{16}$, S.N. Sahana $^{20}$, K.S. Narayan Reddy ${ }^{2}$, Chaurassia B.D. ${ }^{7}$, F.E. Camps ${ }^{13}$, Peter L. Williams ${ }^{9}$, S. Cochrane Shanks ${ }^{10}$, Flecker ${ }^{17}$, Davies and Parson ${ }^{21}$, Bernard Knight $^{18}$ and Kragman ${ }^{15}$.

\section{Conclusion}

In concluded that determine whether an individual has already reached the criminal responsibility age (18 years) or not; evaluation of epiphysis of shoulder joint closure is important after closure of hand and wrist bone epiphyses just before evaluation of iliac crest and ischial tuberosity fusion.

\section{References}

1. Satya Prakash Dixit and R.K. Bansal. Study of ossification centres fusion of elbow joint in 15 to 17 years Garhwali females of Dehradun region. J Indian Acad Forensic Med. Oct.-Dec. 2014; Vol. 36, No. 4; Page 396-398.

2. Reddy KSN. Identification-Growth in Individual bone, In the Essentials of Forensic Medicine and Toxicology. 29th ed. Hyderabad: K. Suguna Devi; 2009. p 6471.

3. Vij K. Textbook of forensic medicine and toxicology principles and practices, $4^{\text {th }}$ edition, Elsevier: India, 2008: P: 54-55.

4. Anju Singh, Dinesh Kumar singh, D.G. Paricharak and harshita Pant. Estimation of age by x-ray examination of distal end of humerus; $\mathrm{J}$ of evolution of Med and Dent Sci: Aug 2014; Vol. 3; Issue 35: Page 9286-9303.

5. Jit I, Kulkarni M. Time of appearance and fusion of epiphysis at medical end of clavicle. Indian J Med Res .1976 May: 64(5):773-82.

6. Galstaun G. A study of ossification as observed in Indian subject. Ind j Med Res 1937; 25(1):267-324.

7. Chaurasia BD Human Anatomy. Regional and applied 2nd ed. CBS Publishers and Distributors. p. 3-11.

8. Gonzales Thomas A. Legal Medicine and Toxicology, New York. 27-28.

9. Williams Peter L, Dyson Mary. Gray's Anatomy 37th ed. p. 404, 408-409.

10. Shanks S Cochrane, Kerley Peter. A Textbook of X-ray Diagnosis Vol 4th, 3rd ed. London, p. 20-21.

11. Waddell LA. Lyon's Medical Jurisprudence for India, Page 56.

12. Parikh CK. "Parikh textbook of Med. Jurisprudence and Toxicology, 5th ed. 1999. C.B.S. Publisher and distributor. p. 2.5-2.14. 
13. Camps Francis E. Gradwohl's Legal Medicine 2nd ed. Bristol: John wright and Sons Ltd. p. 140-141.

14. Basmajian JohnV, Sionecker Charles E. Grant's method of Anatomy. 11th ed., p.372- 373, 378-379.

15. Krogman W M and Iscan M"YF The human : skeleton in Forensic:; Medicin $2^{\text {nd }}$ edition.Illinois: Charles C. Thomas; $p$ .64.

16. Pillai MJS. The study of epiphyseal union for determining the age of South Indians. Indian of Journal Medical Research 1936; 23:p.1015-7.

17. Flecker H. Roentgenographic observations of the times of appearance of epiphysis. J Anat 1932; 67: 188-164.

18. Knight, Bernard. Age Estimation: In, Forensic Pathology, Edward Arnold, A division of Hodder \& Sttoughton London.1996 p. 109-114- 118.

19. Lall, Rand Nat BS. Indian Journal Medical Research (IJMR), Vol 21, p 683.

20. Sahana SN. Locomotor System Osteolog;1 Human Anatomy Vol. I. Sahana S.tVJ. ed. JIAFM, 2005 : 27 (2). ISSN 0971-0973 99 Central Book Agency, 14 Bankh Chantterjee Street Calcutta p. 314-317, 324-325.

21. Davies, DA, Parson FG. The age order of the appearance and union of the normal epiphyses as seen by X-rays. J. Anat., 1927; 62:58-71. 